\title{
Development of a User Preference-Based Educational Game
}

\author{
Jun Karren V. Caparoso ${ }^{1}$, Myrna E. Lahoylahoy ${ }^{2}$, Joy R. Magsayo ${ }^{3}$, Ernesto E. Empig ${ }^{4}$ \\ ${ }^{1}$ Department of Science and Mathematics Education, College of Education, MSU-Iligan Institute of \\ Technology, Iligan City, Philippines, Tel: +63 63223 2349. Mobile No. +63 922892 0862, \\ Email: junkarrencaparoso@gmail.com \\ ${ }^{2}$ Department of Science and Mathematics Education, College of Education, MSU-Iligan Institute of \\ Technology, Iligan City, Philippines, Email: myrna.lahoylahoy@gmail.com \\ ${ }^{3}$ Department of Science and Mathematics Education, College of Education, MSU-Iligan Institute of \\ Technology, Iligan City, Philippines, Email: joyrmags@gmail.com \\ ${ }^{4}$ Department of Information Technology, School of Computer Studies, MSU-Iligan Institute of \\ Technology, Iligan City, Philippines, Email: eempig@gmail.com
}

Doi:10.5296/ijld.v4i2.5104 URL: http://dx.doi.org/10.5296/ijld.v4i2.5104

\section{Introduction}

A game is an immersive, voluntary and enjoyable activity in which a challenging goal is pursued according to agreed-upon rules. They are integral parts of children's cultural and social lives (Rieber, 1996). The NMC Horizon Report: 2013 Higher Education Edition reported that the gamer culture is growing to include a substantial sector of the world's population with the age of the average gamer lowering each passing year. With the implementation of the K to 12 curriculum in the Philippines, the Department of Education may shift to game-based learning to further the development of $21^{\text {st }}$ century skills among digital learners.

Meanwhile, the previously conducted researches on educational games can be grouped into two. There are researches that survey the users' game preferences while others try out a developed educational game to a so-called "target learners" and submit it for experts' evaluation.

It is then this evident gap between the aforementioned groups of researches that urged the researcher to develop an educational game that meets both ends. Specifically, this goal considers the following steps: conducting a game preference survey, developing an educational game based on the result of the survey, evaluating the developed game, and implementing it to target users.

\section{Review of Literature}

According to Protopsaltis (2011), earlier games tended to be based on a behaviourist model which is based on the idea that behaviors are acquired through conditioning which occurs through interaction with the environment. Later games try and incorporate experiential, situated and socio-cultural pedagogical models (Smith, 2003). Felicia (2009) further argued that games generally feature the behaviorist, cognitivist and constructivist approaches. In terms of cognition and learning process, Felicia (2009) disclosed that digital games can be analyzed through well-known models such as Carroll's minimalist theory, Vygotsky's Zone of Proximal Development and Kolb's basic learning model.

A "computer game" according to Garris et al. (2002), usually refers to a game played using a personal computer. Meanwhile, Harris et. al. (2010) classified video games into eight genres, namely; first-person shooter, strategy, sports, role-playing, puzzle, racing, dance/rhythm, and adventure. Among the most popular video games are: Conquer Online 2.0, a massively 
multiplayer online role playing game (MMORPG); K.O.S., a massive multiplayer online (MMO) shooter game; and Tetris Battle, the social version of a classic puzzle game.

Gee (2005) argued that to date, educational games have not been designed using any coherent theory of learning or appropriate research findings. Sotamaa (2007) also argued that there is a growing amount of evidence that professional game designers primarily rely on personal experience and intuitive sense of market demand. According to Crawford (1982), game design is primarily an artistic process and a technical process. He further expressed that a game development sequence may start with choosing a goal and topic, followed by research and preparation, design phase, evaluation of the design, pre-programming phase, programming phase, and lastly, play testing phase.

Meanwhile, according to Rieber (1996), there appears to be a close association between play and learning. The NMC Horizon Report: 2010 K-12 Edition predicted that in two to three years from 2011 through 2016, two technologies with a growing importance may be adopted: game-based learning and open content. Game-based learning has grown in recent years as research continues to demonstrate its effectiveness for learning (The NMC Horizon Report: $2011 \mathrm{~K}-12$ Edition). Indeed, game-based learning can be applied as additional option to classroom lecturing (Kearney \& Pivec, 2007). Most multiplayer virtual environments used today are games (Oblinger, 2006). Likewise, Dondlinger (2007) cited that video games are conducive to the development of specific skills, such as attention, spatial concentration, problem-solving, decision-making, collaborative work, creativity, and ICT skills.

\section{Research Problems}

This study aimed to develop an educational game and evaluate its implications to Science Education particularly in teaching Earth and Space Science. Specifically, it sought to answer the following questions:

3.1 What are the game element preferences of the participants in terms of:

3.1.1 Earth and Space Science topic;

3.1.2 game character;

3.1.3 game setting;

3.1.4 help preferences;

3.1 .5 activity mode; and

3.1.6 scientific attitude?

3.2 How is the educational game developed?

3.3 What is the heuristic evaluation of the educational game according to the:

3.3.1 IT practitioners; and

3.3.2 In-service science teachers?

3.4 What are the perceptions of the target users about the game in terms of:

3.4.1 nature of the game; and

3.4.2 educational value?

3.5 Is the number of target users' game element preferences integrated in the game associated with their perceived educational value of the game? 


\section{Methodology}

\subsection{Research Design}

This study utilized the Research and Development type of research which is summarized below:

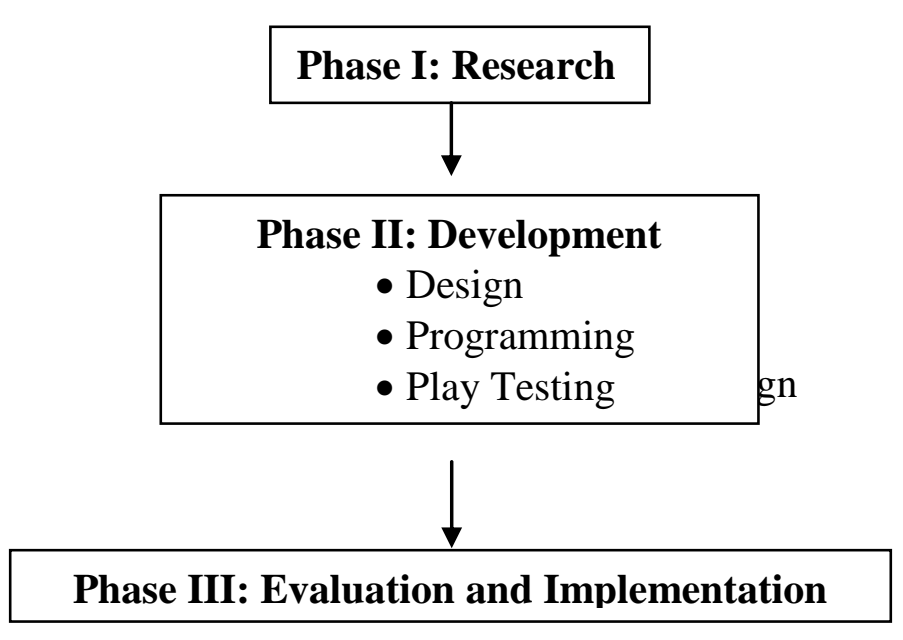

\subsection{Participants}

This study used purposive sampling method. This means that the participants are selected on a certain criterion for a particular purpose. In this case, only those Grade 7 students who play computer games were chosen as participants of the survey. The said group of students was chosen since Earth and Space Science, a component of Integrated Science I, is discussed in the fourth quarter of the Grade 7 curriculum.

In this study, seventy-one (71) male and one hundred ten (110) female Grade 7 students who play computer games, participated in the survey. Eighty-four (84) students were from the science curriculum while ninety-seven (97) from the BEC. The said survey was conducted in the second week of March 2012.

The developed game was evaluated by four (4) Information Technology practitioners (ITP). Three (3) are graduates of BS Information Technology while the other one (1) is a BS Computer Science graduate. They evaluated the technical aspect of the game. Meanwhile, six (6) in-service science teachers (IST) also evaluated the game. They teach both in tertiary and secondary levels. Their evaluation was focused on the presentation of the content and the quality of the game as an instructional material. Further, sixty-five (65) Grade 8 students played the developed game during its implementation on the fourth week of January 2013. In this study, the term "students" may be used interchangeably with "target users".

\section{Results and Discussion}

5.1 Target User Profile and Game Element Preferences

Most of the target users (92.8\%) have ages ranging from 13 to 15 years old wherein about two-thirds $(60.8 \%)$ was female. About two-thirds $(61.9 \%)$ played computer games at least once a day or daily. When asked about the length of play session per game, almost three quarters $(76.7 \%)$ responded that they play one to two hours per game. The questionnaire however did not ask of the time of the day that they play computer games. It was also found out that most of the students $(81.8 \%)$ used desktop computer as game platform with Internet Café $(58.2 \%)$ as the place of play. This simply shows that students do play in Internet Cafés where desktop computers are available. Further, this indicates that only a few students play computer 
games in the school. However, there is still not enough data to conclude that they cut classes to play computer games. When asked about the number of playmates per game, about two-thirds $(61.3 \%)$ responded that they play alone or by themselves.

In terms of game element preferences, just over a half $(54.7 \%)$ of the participants preferred "The Planets" as the topic of the game. "The Planets" is a topic in Astronomy, a component of Earth and Space Science. Based on the Earth and Space Science topic that they chose, the participants were instructed to choose a place where the game shall take place. Since majority preferred 'The Planets" as the topic of the game, it followed that a third (36.3\%) chose "Outer Space" out of the eight options provided in the questionnaire for the game setting.

In terms of game character preference, $53.5 \%$ wanted an Asian game character. "Asian" ethnicity refers to all people in Asia regardless of their cultures. Just over a half $(59.8 \%)$ chose a female character with a "fit" body build (84.1\%) and whose age ranges from 10 to 20 years old $(92.1 \%)$. It appeared that in most cases, girls also prefer a female character while boys also want a male game character. It can be seen also that they put a high regard to their age such that they want a character of their age. The best games provide help options to players when things go wrong. In this study, about two-thirds of the students (67.2\%) preferred to methodically try different solutions to solve a problem instead of being given the answer or hints from a guide (26\%). This simply shows that students want to explore solutions on their own when stuck during gameplay.

Further, it is much important to note that among the six options of activity mode preference, about a fifth of the students (21.8\%) wanted a strategic game. According to Harris et. al. (2010), strategy games are combat games involving resources management and strategy. These are games where players must build and manage units used to harvest resources or attack enemies. Some of these games are played in real-time (RTS) while others are turn-based (TBS). Yet, results show that activity mode preference is not skewed to one option only. The same result was obtained by Amory et. al. (1999) when it was revealed that adventure and strategy games were mostly preferred by the surveyed players because they are stimulating. When asked about the scientific attitude that they want to be integrated in the game, results show "open-mindedness", "inventiveness", and "creativity" as chosen by a total of 39,38 , and 37 students, respectively.

\subsection{Development of the Game}

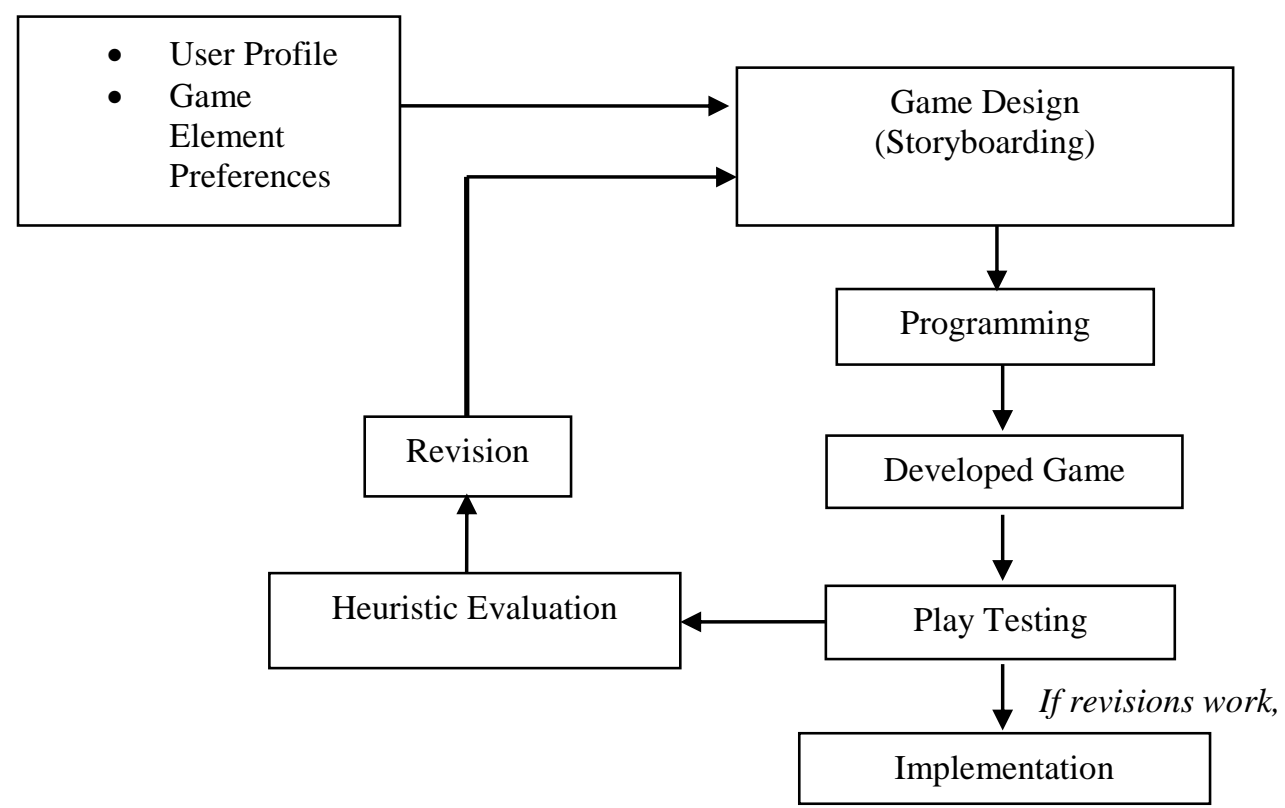

Figure 2. Development flow of the game 
Figure 2 shows the development process of the game. The game was designed following the storyboard which is derived from the target users' user profile and game element preferences. The programming phase was done by a game developer. Play testing was carried out as soon as the first version of the game came out. The developed game was then submitted for heuristic evaluation. After implementing few revisions, the game was implemented to its target users.

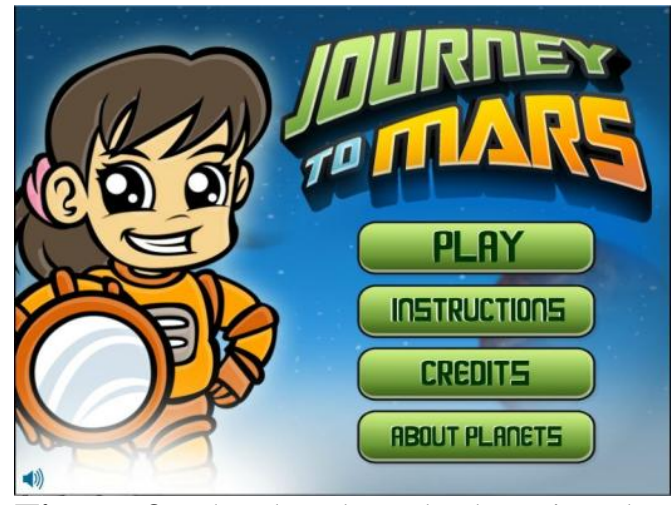

Figure 3. The developed educational game

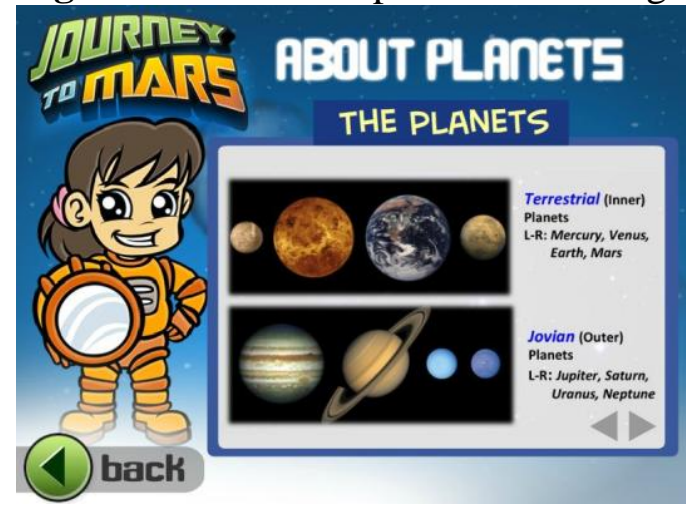

Figure 4. About Planets submenu

The educational game was developed based on the storyboard. The game menu screen shows the title of the game and submenus, such as Play, Instructions, Credits and About Planets (as shown in Figure 4). It also contains a sound button which allows the player to enable/disable all musical backgrounds and effects. The About Planets submenu shows the 10-slide presentation about planets (see Figure 5).

\subsection{Heuristic Evaluation of the Game}

The evaluation ratings shown in Table 1 suggest that the game has successfully given pleasant surprises to the evaluators, sustained their interest, and encouraged immersion through the game's story. On the educational side, the game must have educated the evaluators about planets. The developed game was then revised based on the evaluators' suggestions. 
Table 1 Heuristic evaluation of the game.

\begin{tabular}{|c|c|c|c|c|}
\hline \multirow[t]{2}{*}{ Heuristic Category } & \multicolumn{3}{|c|}{ Mean Rating } & \multirow[t]{2}{*}{ Remarks } \\
\hline & IST & ITP & Overall & \\
\hline $\begin{array}{l}\text { Game Usability and } \\
\text { Mechanics }\end{array}$ & 3.4 & 3.3 & 3.4 & $\begin{array}{l}\text { The game supports this } \\
\text { heuristic category well. }\end{array}$ \\
\hline Gameplay & 2.9 & 3.3 & 3.1 & $\begin{array}{l}\text { The game supports this } \\
\text { heuristic category well. }\end{array}$ \\
\hline $\begin{array}{l}\text { Emotional Immersion } \\
\text { and Educational Value }\end{array}$ & 3.4 & 3.4 & 3.4 & $\begin{array}{l}\text { The game supports this } \\
\text { heuristic category well. }\end{array}$ \\
\hline Overall & 3.2 & 3.3 & 3.3 & $\begin{array}{l}\text { The game supports this } \\
\text { heuristic category well. }\end{array}$ \\
\hline
\end{tabular}

5.4 Perceptions of the Target Users about the Game

Almost three-quarters $(73.8 \%)$ of the students agreed that the game can be completed in 1 to 2 hours. Most of the participants $(96.9 \%)$ also said that the game can be played in Internet Cafés in a desktop computer. When asked if the game can be played by a single player as they once preferred, only one said "No". Almost all of the students $(98.5 \%)$ said that the game is about "Planets" while all (100\%) of them agreed that the game is set in "Outer Space". About two-thirds (70.8\%) affirmed that the game character is "female" with "fit" body build (84.6\%), aged "10 to 20 years old" (92.3\%), and with "Asian" ethnicity (81.5\%). Most of the players $(93.8 \%)$ perceived that the game allows them to "methodically try different ways to solve a problem" while $92.8 \%$ of the students confirmed that the game activity mode is "strategic". Finally, $90.8 \%$ accepted that the game fosters open-mindedness, inventiveness and creativity.

These results simply confirmed that students' game element preferences were integrated in the developed game. This further implies that this study has achieved one of its objectives which is to develop a game based on students' preferences.

The students strongly agreed that the game helped them learn and improved their understanding about planets. They also strongly agreed that they enjoyed and had fun while learning about planets as they played the game. When used in the class, they strongly agreed that the game will improve their understanding about planets. Further, the students agreed on the motivational value of the game in studying about the topic "planets". The students also strongly agreed that they would like their Earth and Space Science teacher to use the game in class.

Meanwhile, most of the students $(90.8 \%)$ claimed to have exercised problem solving skills in playing the game while almost three-quarters $(75.4 \%)$ have done risk-taking. On the other hand, almost all of students $(98.5 \%)$ believed that they exercised critical thinking while most $(95.4 \%)$ of them claimed of exercising information and media literacy skills. This confirmed the findings of Felicia (2009) that games can develop cognitive, spatial and motor skills and help improve ICT skills. Further, the said results show that the educational game supports the objective of the $\mathrm{K}$ to 12 science curriculum.

5.5 Relationship between Students' Game Element Preferences and Game's Perceived Educational Value 


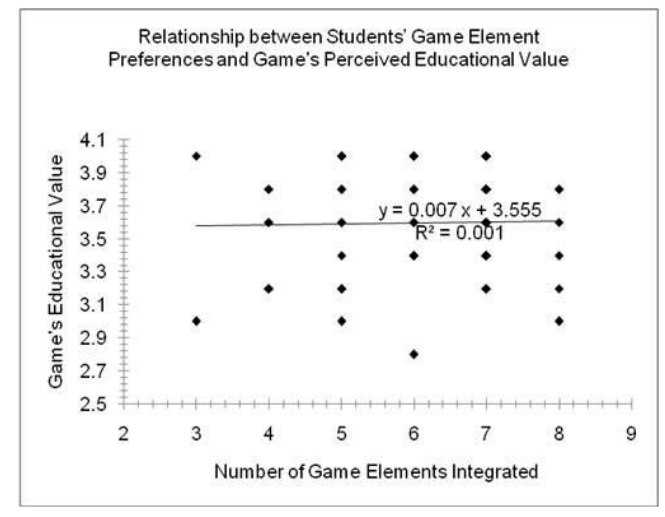

Figure 5. Scatter plot of students' game element preferences and game's perceived educational value

Figure 5 shows that only a very slight positive relationship exists between the dependent variable (game's perceived educational value) and independent variable (number of game element preferences integrated in the game. Further, the $\mathrm{z}$ test which determined the significance of the correlation coefficient $r$ revealed that the relationship between the variables is not significant.

\section{Conclusions}

The educational game has successfully packaged the user profile and game element preferences of the target users into a functional, usable, error-free, interesting, entertaining and engaging educational game which integrates $21^{\text {st }}$ century skills. Moreover, the number of preferred game elements integrated in the game is slightly related to the game's perceived educational value. While many games claim to be educational, the developed game is still unique and relevant because it is based on actual students' user profile and game element preferences.

\section{References}

Crawford, C. "The Art of Computer Game Design". Stanford University. 1982. Online.03December2010.http://arcarc.xmission.com/Magazines\%20and\%20Books/Art\% 20of\%20Game\%20Design.pdf

Dondlinger, M. J. (2007). Educational Video Game Design: A Review of the Literature. Journal of Applied Educational Technology, 4, 1. Online. 8December2010. http://www.eduquery.com/jaet/JAET4-1_Dondlinger.pdf

Felicia, P. "Digital Games in Schools: A Handbook for Teachers". European Schoolnet. 2009. Online. 08December2010. http://games.eun.org/upload/gishandbook_en.pdf

Garris, R., Ahlers, R. \& Driskell, J. E. "Games, Motivation, and Learning: A Research and Practice Model”. Simulation \& Gaming. 2002. Online. 10December2010. http://diegolevis.com.ar/secciones/Infoteca/vj_motivacion.pdf

Gee, J. P. (2005). What Would a State of the Art Instructional Video Game Look Like? Innovate Journal of Online Education,1,6. Online. 08December2010. 
http://www.innovateonline.info/pdf/vol1_issue6/What_Would_a_State_of_the_Art_Instr uctional Video_Game_Look_Like_.pdf

Harris, F. C., Folmer, E. and Yuan, B. (2010). Game accessibility: A Survey. Springer Verlag, 10,81-100.Online.10December2010. http://www.cse.unr.edu/ fredh/papers/journal/29gaas/paper.pdf

Johnson, L., Adams, B., Cummins, M., Estrada, V., Freeman, A. \& Ludgate, H. "NMC Horizon Report: 2013 Higher Education Edition”. The New Media Consortium. 2013. Online. 28February2013.http://www.nmc.org/system/files/pubs/1360189731/2013horizon-report-HE.pdf

Kearney P. \& Pivec, M. (2007).Games for Learning and Learning from Games.

Informatica, 31, 419-423. Online. 08December2010.http://www.informatica.si/PDF/314/07Pivec-Games.pdf

Oblinger, Diana. "Simulations, Games and Learning". EDUCAUSE Learning Initiative.2006. Online. 08December2010.

http://net.educause.edu/ir/library/pdf/ELI3004.pdf

Protopsaltis, A. "Learning Theories and Serious Games". Serious Games Institute. 2011. Online. 21February2013.http://www.meducator.net/dissemination.activities/files/163.pdf

Rieber, L.P. (1996). Seriously Considering Play: Designing Interactive Learning Environments Based on the Blending of Microworlds, Simulations, and Games.

Educational Technology Research \& Development, $\quad 44, \quad 43-58$.

Online.8December2010. http://lrieber.coe.uga.edu/play.html_

Smith, M. K. "Introduction to Informal Education". The Encyclopedia of Informal Education, 2003. Online. 20February2013. http://www.infed.org/i intro.htm

Sotamaa, Oli. (2007). Perceptions of Player in Game Design Literature. Proceedings of DiGRA 2007 Conference, 456-465. Online. 10December2010. http://www.digra.org/dl/db/07311.59383.pdf_

Doi:10.5296/ijld.v4i2.2161ＵRL: http://dx.doi.org/10.5296/ijld.v4i2.2161 